\title{
An Examination of Causes and Consequences of Conflict Between Legislature and Executive in Cross River State, Nigeria
}

\section{Bassey, Antigha Okon [Ph.D]}

Lecturer, Department of Sociology University of Calabar P.M.B II 15 Calabar, C.R.S. Nigeria E-mail: antigha2k4@yahoo.com

\section{Raphael Pius Abia}

Senior Lecturer, Department of Sociology University of Calabar P.M.B III5 Calabar, C.R.S. Nigeria

\section{Omono, Cletus Ekok}

Lecturer, Department of Sociology, University of Calabar

Email:cletusomono@yahoo.com

\section{Bassey, Umo Antigha}

Unified Local Government Service Commission Calabar; C.R.S. Nigeria

Doi:10.5901/ajis/2013.v2n1p179

\section{Abstract}

The study reviewed legislative-executive relationship in Cross River State fourth republic democratic government. The paper examines causes and consequences of conflict which was discovered as the nature of the relationship. Expost facto research design was adopted in which 100 sample was selected and studied. Data obtained was analysed using simple percentage analysis. The study also relied on secondary data obtained form archival materials. Discussion revealed the existence of harmony and conflict. The empirical test shows that the relationship was essentially conflictual. Causes of conflict discovered include: pride and personality clash, perceived executive dominance, ignorance of constitutional provisions, functional overlapping and performance of legislative oversight function. Consequences of conflict identified include: delay in discharge of duties, stalemate, disunity and outright opposition. The study recommended mutual respect as panacea to conflict, dialogue, bargaining and negotiation as well as constant interaction in workshop conferences and meetings. The study maintains that harmonial legislative-executive relationship is essential for the growth, development and sustenance of Nigeria's nascent democracy.

Keywords: Conflict, Legislature, Executive, Relations, Causes, Consequences

\section{Introduction}

One of the major factors threatening Nigeria's nascent democracy today is conflict between the executive 
and legislative arms of government. Contemporary development at the federal, state and local government levels proved that the relationship between the legislature and executive branch is not harmonious. Success and failure of government, as well as governmental policies, programmes and projects are all considered in many quarters as consequences of the nature of relationship existing between the executive and legislature.

The major aim of this paper is to examine the relationship between executive and legislature in Nigeria is conflictual with particular reference to Cross River State Government. The paper will attempt to unravel the causes and consequences of conflict, as well as provide solutions for reducing or eliminating conflict between executive and legislature to foster harmony. It is hoped that the paper will provide guidelines to members of the executive and legislative branch of government for establishing harmonious relationship in policy making, good governance and democratic reconstruction.

Legislature refers to institution that has the power to make or change laws. A legislative institution is any institution that has the power to make laws. The executive refers to the part of government that is responsible for making sure that laws and other decisions are carried out or implemented in the manner they were directed or planned. The third branch of government is the judiciary that interpret laws. This paper focuses on the legislature and executive branches of government in Nigeria. At the federal level is the Executive Council comprising the President and his Ministers responsible for various departments and functions of government. The federal legislature comprises the Senate and the House of Representatives. At the state level is the State Governor and his commissions responsible for various departments as executive, and the House of Assembly as the legislature. This paper examines specifically the relationship between the executive and legislative arms of government in Cross River State.

\section{Conceptual Analysis and Review}

Conflict is a behaviour by a person or group that inhibits the attainment of goals by another person or group (Riggio, 2000). In ordinary usage, conflict is regarded as a state of opposition marked by fight or struggling. Perception of legislative and executive conflict is not far from Riggio (2000) definition of conflict. Legislative-executive conflict denotes a situation whereby the legislature is opposed to the executive and vice versa in matters of policy and their perception of the value of good governance. It is a state of partial or absolute incompatibility where one arm is in constant confrontation with the other (Bassey, 2000).

In 200I, two years into the commencement of Fourth Republic in Nigeria democratisation process, conflict between the National Assembly (House of Representatives and Senate) and the executive at the Federal level of government existed, which was widely presented by the press (The Punch, 200I). The conflict transcends the relationship between state executive and the legislature in various states and even spilling to the local government councils. Major effect of such conflict was the impeachment of key personnel in both executive and legislature, such as Speakers, Deputy Speakers and Governors etc (Punch, 2007).

Rockman (1983) identified four major elements in legislative-executive relations namely, values and perspectives of governance; the major players, actions and institutions; and legislative control and supervision of executive behaviour, which is referred to as oversight. These elements are the likely areas which conflict emerged between the two arms of government. Effective management of these key elements will reduce if not eliminate relational conflict in governance.

The relationship existing between governmental units or arms may take diversity of nature, the focus of this research on conflict should not be misconstrued as the only form or nature of relationship existing between and among arms of government. The nature and diversity of such relationship is usually treated under "Inter-governmental Relations" (IGRs). Adamolekun (I982) defined Intergovernmental 
Relations as "the interactions that take place among the different levels of government within a state". Looking at this definition, it excludes in its entirety legislative-executive relations within a particular level, because neither the executive nor legislature are levels of government, as in Nigerian federation, which consists of federal, state and local as levels of government.

Legislative-Executive relations is the interaction and total transaction that takes place between the Executive and the Legislative arms at a particular level of government where both institutions exist (Bassey, 2000). The nature of intergovernmental relations and executive-legislative relations are in practice identical as both may involve conflict, cooperation, negotiation, bargaining and conciliation. This study focuses on conflict which is one of the prevailing relationship between legislature and executive at various levels of government in Nigeria.

According to Loewenberg, Patterson and Jewell (I983), legislature is a body which promulgates laws, which authenticate and legitimise commands as to what citizens of a state can do or cannot do. Basic components or characteristics of legislature include: equal status of members, law-making and representation based on free and periodic elections. Appadorai (1975) categorised the functions of legislature as legislation, administration, financial appropriation and ventilation of grievance. Legislation is the most important function involving law making, administrative function has to do with light publicity on the act of governance by enduring check and balance on the executive branch. The financial function has to do with the appropriation power of legislature, while ventilation of grievance reflects the responsiveness of the legislature to public opinion and request in matter of state policy.

As defined by the constitution, no arm of government is expected to usurp the functions of another arm. That is for example, executive has no power to expend what was not appropriated of the legislature as this will be conflict. Whether this constitutional provision is respected in the routine activities of arms of government in Cross River State in particular and Nigeria in general is what this paper is set to determine.

\section{Legislative-Executive Relations in Cross River State}

The fourth republic Executive and Legislature in Cross River State commenced in 1999 with the rebirth of democracy in Nigeria. Despite the fact that at inception the Executive arm was led by a Governor from People's Democratic Party (PDP) and the executive led by Speaker from the All Peoples Party (APP), Bassey (2000) noted harmonious and cordial relationship void of conflict between executive and the legislature. The harmonious relationship was marked by cooperation, bargaining and negotiation as against conflict. Murray (1975) noted that when the executive and legislature are headed by different parties, there is bound to exist conflict which is likely to render the government ineffective as a result of disagreement in policy directions. Murray's (1975) observation did not hold true in Cross River State at this stage.

This is not to say that there was no area of disagreement between executive and legislature in Cross River State but such were resolved through negotiation before disagreement transformed into conflict. For instance Rural Development Commission Bill sent to executive emerged from the House as Rural Development Authority Act. This happened without conflict because of the existence of machinery for cooperation to finetune grey areas. The cordial relationship in the fourth Republic saw to the submission and passage of the following Bills from the executive by the House.

I. Cross River State Rural Development Commission Bill - 1999

2. Cross River State Forestry Commission Bill - I999

3. Cross River State Supplementary Appropriation Bill - 1999

4. Cross River State Year 2000 Appropriation Bill - I999 
5. Prohibition of the Indiscriminate Dumping of Refuse on the Streets, Drains and Public Places in Cross River State Bill - 2000

6. Girl-Child Marriage and Female Circumcision (Prohibition) Bill - 2000

7. Cross River State Local Government Bill - 2000

At the end of the legislature tenure in 2003 over IO more bills were passed and I2 resolutions made (Cross River Radio, 2003).

The situation in Cross River State differs significantly from what was obtainable in the National Assembly at the same period. It was reported in the press that Sultan Maccido (The Sultan of Sokoto and Head of Islamic Religion in Nigeria) sues for cooperation among arms of government in the federal level during the meeting of the National Executive Council of Nigeria Supreme Council for Islamic Affairs (Chronicle, 2000). After 1999 the situation changed and relationship of the two arms of government degenerated to conflict. The Nigerian Watch (2000) noted confrontation between the leader of the House and Executive Arms of Government and subsequent removal of the leader, as noted:

\begin{abstract}
"The travails of Honourable Ada fits into popular belief that he somehow engineered the Assembly woes through unnecessary confrontations with the executive arm of government and now his exit from the headship provide vista for new relationship."
\end{abstract}

This condition shows that personal attribute of the leader (speaker) of the House later led to conflictual relationship between legislature and executive in Cross River State which was handled through the removal of the speaker, which indicates subordination of the legislature to the executive. To what extent the journalistic insinuation held true or false motivated this investigation, to examine the causes and consequences of executive-legislative conflict.

\title{
4. Theoretical background
}

Conflict theory lays emphasis on the importance of interest in construction and implementation of norms and values and the manner in which pursuit of interest caused different types of conflict which forms part of normal life in the society. Major proponents of conflict their include Marx (I964) and Dahrender (1959). According to conflict theorists, society is made up of different groups with varying interest competing with one another for hegemony and control of power, authority and allocation of society's resources. Conflict theory provides a framework for the understanding and analysis of relationship existing between executive and legislature as competing groups in a state struggling for the control of state policy apparatus, as well as control and allocation of state resources. But to what extent legislative-executive conflict will produce change in terms of socio-economic development and consolidation of democracy necessitated the utilisation of functional aspects of social conflict in investigation.

Coser (1956) examined the functions of social onflcit in his attempt to incorporate the analysis of social conflict into structural functionalism. Social structure here denotes network of interaction, while function refers to consequences of action in a system that the action takes place. The question is, what function does conflict produce in terms of the interaction of legislature and executive? It is the theoretical synthesis of conflict theory and structural functionalism that will specifically guide the analysis of executive-legislative conflict in terms of examining its causes and consequences.

\section{Methodology}

In conducting this investigation, survey was carried out in order to permit the use of variety of data 
collection techniques. Such survey techniques utilised for gathering data include: interview, questionnaire and non-participant observation. Secondary data from newspapers, electronic media and other archival materials were also utilised. The area of study is Cross River State, one of the 36 states in Federal Republic of Nigeria with Calabar as its state capital and a total of eighteen (I8) local government areas.

Table I: Local Government Area in Cross River State and their population

\begin{tabular}{|l|l|c|}
\hline S/No & Local Government Area & Population \\
\hline I & Abi & I44,317 \\
\hline 2 & Akamkpa & I49,705 \\
\hline 3 & Akpabuyo & 272,262 \\
\hline 4 & Bakassi & 31,641 \\
\hline 5 & Bekwara & I05,497 \\
\hline 6 & Biase & I68,113 \\
\hline 7 & Boki & 186,611 \\
\hline 8 & Calabar-Municipal & I83,681 \\
\hline 9 & Calabar South & 191,515 \\
\hline I0 & Etung & 80,036 \\
\hline II & Ikom & 163,691 \\
\hline I2 & Obanliku & 109,633 \\
\hline I3 & Obubra & 172,543 \\
\hline I4 & Obudu & 161,457 \\
\hline I5 & Odukpani & 192,884 \\
\hline I6 & Ogoja & 171,574 \\
\hline I7 & Yakurr & 196,271 \\
\hline I8 & Yala & 211,557 \\
\hline & & $2,892,988$ \\
\hline
\end{tabular}

Source: National Population Commission, 2009 (2006 Census Figure)

The investigation focus mainly on the relationship existing between the legislative and executive branch of government in the state administering 2,892,988 people residing in the state (as at 2006 census). The population of the study was very large as it involved the entire executive, legislature, bureaucrats, politicians and members of the public who observed and contributed to the activities of the state policy formulation and implementation process. Because of the largeness of the population, a sample of IOO subjects were randomly chosen by the investigators, comprising IO legislators, I0 members of executive branch, 20 public servants, 20 party politicians and 40 members of the general public. Size of sample cluster selection was in proportion to their general population. The subjects were accidentally selected at various locations such as: State House of Assembly Complex. State Civil Service Secretariat, Governor's Office complex and the two tertiary institutions all in Calabar. Questionnaire was constructed as appropriate survey instrument. Questionnaire analysed statistically using simple percentage, comparison in tables (Osuala, 1982; Obasi, 1999). The questionnaire instrument required 'Yes', 'No' or 'Undecided' responses.

\section{Data Presentation and Analysis}

The following demographic data were obtained. 
Table 2: Demographic Data

\begin{tabular}{|c|c|c|c|c|c|c|c|c|c|}
\hline \multicolumn{2}{|l|}{ Age } & \multicolumn{2}{|c|}{ Education } & \multicolumn{2}{|c|}{ Social Status } & \multicolumn{2}{|c|}{ Religion } & \multicolumn{2}{|c|}{ Sex } \\
\hline Range & Freq & Qualification & Freq & Category & Freq & Religion & Freq & Sex & Freq. \\
\hline $18-30$ & 39 & Post Graduate & $\mathrm{I} 2$ & Legislature & $\mathrm{IO}$ & Christian & 88 & Male & 67 \\
\hline $3 I-40$ & 24 & B.Sc./HND & $3 I$ & Executive & I0 & Muslim & 3 & Fem. & 33 \\
\hline $4 I-50$ & $3 \mathrm{I}$ & OND/NCE & I8 & Public Servant & 20 & Atheist & I & - & - \\
\hline $5 I-60$ & 4 & B.Sc. & 36 & Party politician & 20 & $\overline{A T R}$ & 8 & - & - \\
\hline \multirow{2}{*}{$\begin{array}{l}6 I \text { and } \\
\text { above }\end{array}$} & \multirow[t]{2}{*}{2} & \multirow[t]{2}{*}{ FSLC/Others } & \multirow[t]{2}{*}{3} & Student & $2 \mathrm{I}$ & \multirow[t]{2}{*}{-} & \multirow[t]{2}{*}{ - } & \multirow[t]{2}{*}{-} & \multirow[t]{2}{*}{-} \\
\hline & & & & Others & I9 & & & & \\
\hline Total & 100 & & 100 & & 100 & & 100 & & 100 \\
\hline
\end{tabular}

Source: Field survey 2000

In the demographic data, 39 subjects were between the ages of I8-30, 24 (3I-40), 3I (4I-50), 4 (5I-60) and 2 (6I and above). This indicates that politically active people concerned with legislative, executive affairs were mostly between the ages of $18-50$ years, as frequency decline after the ages of 50 years. Many Cross Riververians are educated as over $97 \%$ attended secondary school and above which primarily negates the classification of the state as educationally disadvantaged state. But the locations where subjects were selected caused the increased number of educated subjects. Invariably, if subject selection was spread to rural areas, the true educational and literacy position of the state would have been revealed. The social category of respondents was purposively determined by the researchers in order to enhance unbiased response and prevent responses being one-sided. With $88 \%$ Christians among respondents, the state is predominantly a Christian state (Bassey, Ojua, Ering, 2012). The increase of male to female being $67 / 33$ negates the demographic distribution in which females are more than male (NPC, 2009) and shows that males participate in political issues especially as regards observation of executive-legislative relationship more than females.

\section{Analysis of Substantive Data and Findings}

From the discussion above, it is noted that the relationship is not static, at one time it is conflictual and at another harmonious. In view of this situation, statistical analysis using simple percentage analysis was utilised to determine actual relationship. The first guiding null hypothesis under test was;

HO: There is no conflict between executive and legislature

The statement number one (I) in the instrument stated that, "There is conflict between executive and legislature". Response to this statement is presented in table 3.

Table 3: Field Observation for Hypothesis I, Statement I and Percentage

\begin{tabular}{|l|c|c|c|c|}
\hline Statement & Yes & No & Undecided & Total \\
\hline $\begin{array}{l}\text { There is conflict between } \\
\text { executive and legislature }\end{array}$ & $59(62.77)$ & $23(24.47)$ & I2(12.77) & $94(100 \%)$ \\
\hline
\end{tabular}

Source: Field survey (2000)

From Table 3 above, favourable responses "Yes" to the statement which negates the null hypothesis is $62.77 \%$, while unfavourable responses "No" is $24.47 \%$. Undecided is $12.77 \%$. Consequently, the null 
hypothesis was rejected. The finding is that there is conflict between executive and legislature in Cross River State.

The second task of the study was to unravel the causes of executive-legislative conflict and Table 4 presents data obtained in the field investigation.

\section{Table 4:}

\begin{tabular}{|l|l|l|l|l|l|}
\hline S/No & Statement & Yes & No & Undecided & Total \\
\hline 2 & $\begin{array}{l}\text { Legislative-Executive conflict is } \\
\text { as a result of pride and } \\
\text { personality clash }\end{array}$ & $66(70.21 \%)$ & $24(25.55 \%)$ & $4(4.26 \%)$ & $94(100 \%)$ \\
\hline 3 & $\begin{array}{l}\text { Conflict between legislature and } \\
\text { executive is caused by perceived } \\
\text { executive domination }\end{array}$ & $59(62.77 \%)$ & $30(31.91 \%)$ & $5(5.32 \%)$ & $94(100 \%)$ \\
\hline 4 & $\begin{array}{l}\text { Conflict is due to ignorance of } \\
\text { the constitution by executive } \\
\text { and legislature }\end{array}$ & $70(74.47 \%)$ & $21(22.34 \%)$ & $3(3.19 \%)$ & $94(100 \%)$ \\
\hline 5 & $\begin{array}{l}\text { Functional overlapping is a } \\
\text { major cause of conflict }\end{array}$ & $54(57.45 \%)$ & $28(29.79 \%)$ & $12(12.77 \%)$ & $94(100 \%)$ \\
\hline 6 & $\begin{array}{l}\text { Performance of oversight } \\
\text { functions by legislature often } \\
\text { result in conflict }\end{array}$ & $63(67.02 \%)$ & $22(23.40 \%)$ & $9(9.57 \%)$ & $94(100 \%)$ \\
\hline
\end{tabular}

Source: Field survey (2000)

Five variables were purposively examined in tune with Rockman (I983) identification of causes of legislative-executive conflict namely: pride and personality clash, executive dominance, ignorance of the constitution, functional overlapping and legislative performance of oversight function. Statement 2 "legislative-executive conflict is as a result of pride and personality clash", 'Yes' responses were 70.21\%, 'No' responses $25.53 \%$, while undecided was $4.26 \%$. The favourable responses as against unfavourable responses indicates that pride and personality clash are part of the causes of executive-legislative conflict. The fourth variable considered was ignorance of constitutional provision of balance of power as organs of government are expected constitutionally to operate co-ordinately, 'Yes' was $74.47 \%$, 'No' $22.34 \%$ and undecided $3.19 \%$. Since favourable responses 'Yes' was overwhelming, ignorance of constitutional provision was accepted as part cause of executive-legislative conflict. The analysis showed that overlapping with high positive response 'Yes' $57.45 \%$ was also a factor in executive-legislative conflict, likewise legislature performance of oversight function with $67.02 \%$ positive 'Yes' responses.

In determining the consequences of executive-legislative conflict with an open-ended question, which states thus: "What do you consider to be the consequences of legislative-executive conflict on Nigeria nascent democracy?”

Only $73(77.66 \%)$ of respondents responded to the questions out of 94 . Twenty one (2I) respondents left the answer space blank (22.34\%). The following consequences were extracted:

I. Stalemate of state administration

2. Delay in discharge of official function

3. Obstacle to development of democratic institution and culture

4. Disunity between parties and intra-party disharmony

5. Inter-party opposition in government

6. Weakness of parties and their possible disintegration

7. Check and balance (accountability) 
8. Guarantee independence of legislature

9. Mitigate executive excesses

The above nine statements represented consequences of legislative-executive conflict obtained from the responses to open-ended question. In view of the above findings, it is established that there was conflict between executive and legislature in the first legislative session of fourth republic democratic process commencing from 1999 in Cross River State, Nigeria.

\section{Discussion}

Previous discussion in this study reveals the existence of harmony at the onset of the democratic process in 1999 between the executive and legislature in Cross River State, but as events unfold, the relationship degenerated from harmony marked by negotiation and bargaining to conflict. This is evidenced in the findings of the investigation which indicates high positive responses to the test statement "There is conflict between executive and legislature" being $62.77 \%$. Since the executive was headed by People's Democratic Party and the legislature headed and dominated by All Peoples Party, conflict was inevitable as Murray (1975) explained that whenever executive and legislature are controlled by different parties, conflict must exist and Cross River State proved not to be an exception.

The study also identified causes of executive legislative conflict in Cross River State to include pride and personality clash, perceived executive dominance, ignorance of constitutional provisions, functional overlapping and performance of legislative oversight functions. These discoveries follow Rockman (1983) postulate of these four variables mentioned above as the possible causes of conflict between executive and legislature in any democratic system. Though conflict exists, Rockman (1983) maintains that these variables refine themselves as they exist over time. Thus as democracy persists, the factors will be perfected by other democratic dynamics which will cause them to cease to function as sources of conflict. Such democratic dynamics include constitutional amendment, changes and development.

The study also presented consequences of executive-legislative conflict. Some of the consequences are negative, while some are positive. For instance, delay in the discharge of official function and disunity between and among different parties threatens the continuity of the state, while check and balance foster accountability, leading to economic efficiency, progress and development. Every polity should examine such consequences and manage it properly in order to ensure dividend of democracy to citizens.

The instrument also presented responses to the question "How can conflict between legislature and executive be reduced or eliminated in order to ensure harmony?" The respondents provided the following responses as strategy of ensuring legislative-executive harmony: Transparency in the conduct of state affairs; regular consultation; dialogue in resolving crises; regular interactions in meetings, workshops, conferences, dinner and other officials functions; effective and regular communication; integration of legislators into executive delegations; mutual respect for each other; reorientation of legislators and executive on provisions of the constitution with regards to functions and roles.

\section{Conclusion and Recommendation}

Understanding legislature-executive relation is crucial to building democratic values and ideal for the sustenance of basic institutions and ensuring effective interaction towards democratic development. The paper reveals the varieties of relationship and interaction that exist between legislature and executive, which includes: bargaining, negotiation, conflict and harmony. Bargaining and negotiation themselves may result in either conflict or harmony. The discussion in the research shows that there exists both 
period of conflict and harmony in the relationship between legislature and executive in Cross River State. The findings of empirical text indicates specifically conflictual relationship.

The paper specified causes of conflict between executive and legislature which includes; pride and personality clash, perceived executive dominance, ignorance of constitutional provisions, functional overlapping and legislative performance of oversight function. The paper also outlines consequences of conflict among which are: stalemate of state administration, opposition, disunity, delay in discharge of governmental functions among others. Mutual respect between executive and legislature is one cardinal panacea to the conflict. It is also recommended that dialogue, interaction in workshop, conferences and meetings should be considered as measures of ensuring cordial and harmonious relationship.

\section{References}

Adamolekun, Ladipo (1983) Public Administration: A Nigerian and Comparative Perspective, London: Longman Appadorai, A. (1975) The Substance of Politics, Madras: Oxford University Press

Bassey, Antigha (2000) "Issues in legislative affairs: A study of Cross River State House of Assembly" Legislative Fellow Research Report, Ibadan: The Institute of Social Science and Administration (TISSA), Vol. I,2,3

Bassey, A. O., Ojua, T. A., and Ering, S. O. (2012) "The Impact of Protestant Religion on Industrial Development in Nigeria. A Study of Protestants in Calabar", African Journal of Social Sciences, Vol. 2, No. 3, pp. I56165

Constitution of the Federal Republic of Nigeria 1999, Lagos: Federal Government Printing Press

Cross River Radio (2000) Morning News 6.30am, $5^{\text {th }}$ and $6^{\text {th }}$ June, Calabar, Cross River Broadcasting Corporation. Cross River State House of Assembly (1999) Votes and Proceedings No. 22, November 9

Coser, L. (1956) Masters of Sociological Thought. New York: Harcourt Brace Jovanovich The Nigerian Chronicle (2000) Assembly Report, Nov. 6, I3, I9, 23

Dahrendorf, R. (1959) Class and Class Conflict in an Industrial Society, London: Routledge and Kegan Paul

Marx, K. (1964) The Economic and Philosophical Manuscripts, New York: International Publishers The Nigerian Watch (2000) Friday Nov. 17

National Population Commission (2009) 2006 Census Result. Lagos: Government Printing Press

Obasi, Isaac (1999) Research Methodology in Political Sciences, Enugu: Academic Publishing Company

Osuala, C. (1983) Introduction to Research Methodology, Onitsha: Africana-FEP Publishers

Murray, S. (1975) Urban Politics, Cambridge: Winthrop Publishers

Rockman, B. (I983) "Legislative-Executive Relations" in Gerhard Loewenberg, Samuel, P. and Malahis, J. (eds.) Handbook of Legislative Research. Cambridge: Harvard University Press

Loewenberg, G., Patterson, S. and Jewell, M. (1983) Handbook of Legislative Research. Cambridge: Harvard University Press

Reggio, R. (2000) Introduction to Industrial/Organisational Psychology, New Jersey: Prentice Hall 
